Theories \& Applications the International Edition

Printed Version: (ISSN 2090-5262)

Online Version: (ISSN 2090-5270)

November 2011, Volume 1, No. 3 Pages (74 -92)

\title{
The Civil and Criminal Means of Protecting Brand Name in Sports Institutions
}

\author{
Hassan Ahmed El-Shafei*, Hamima Ibrahim Naser Hashish**, \\ Nesreen Abdullah Ahmed Armanazy***
}

The research aimed to identify The Civil and Criminal Means of Protecting Brand name in Sports Institutions and that through: the standards contained in the agreement on the Rights of Intellectual Property (TRIPS Agreement) of civil protection for the Brand and the Famous Logo by the law (Egyptian, Saudi, English and American laws) of the criminal protection of the Brand and the Famous Logo (Egyptian and Saudi laws). As per the research procedure, the research followed a descriptive scanning approach. The study society covered a sample of (69) senior management of certain sports establishments (Sport clubs sports federations). A questionnaire was used as a tool for collecting data and information. The most important results came as follows: the research sample consented that civil protection warned acts whose nature may create confusion with other competitors, their products or their various activities, in addition to that, any statements or allegations that may mislead the public as to the nature of the goods, their production or to sport services. The owner of the Brand has the right for legal protection on the basis of illegal competition whether the Brand is registered or unregistered. If the Brand is unregistered the protection will be on the basis of unfair competition. Anyone who forges or reproduces a registered Brand in such a way as to mislead the public will be prosecuted in accordance with the law. Crimes committed on brands, forgery and reproduction: are the violation of a Brand owned to others and to be put with malice by its violator on their products. The most important recommendations are: The development of an Arab Agreement for the property rights of the brand, the establishment of specialized courts for intellectual property disputes of all kinds using compensations as a deterrent, the need for all administrative and legal procedures when registering sports events and sports institution Logos, the renewal of the registration Brands in accordance with the rules in force, tightening regulatory actions against violators of the sports institutions Brands.

\section{Introduction}

A nyone launching a sport product or sport service, whether on-line or off-line, will put a lot of thought into what to offer and how to go about offering it. In particular, most businesses invest a lot of time and money in creating a brand which will appeal to consumers and set its sport products or services apart from competitors. For this reason, a business will not want anyone else pretending to be associated with it and piggy-backing on its reputation.

Before settling on a brand, you should carry out

\footnotetext{
*Professor, Sports Administration Department,TheFaculty of Physical Education for Girls, Alexandria University, Egypt.

**Assistant Professor, Sports Administration Department, TheFaculty of Physical Education for Girls, Alexandria University, Egypt.

***Lecturer, Sports Administration Department, TheFaculty of Physical Education for Girls, Alexandria University, Egypt.
}

some research to ensure that no one else is already using the proposed brand. Searching through an internet search engine and on the Companies House web site will be a good starting point to determine whether another business is trading under the name or using the brand.

Protecting your own rights is important, but it is equally important to ensure that you do not infringe the rights of other people. You should therefore check that someone has not already registered your chosen brand name as a trade mark. A basic search can be carried out on the Intellectual Property Office (IPO) web site, or Trade Mark Agents can carry out a more detailed trade mark clearance search for you. 
A well-known Brand is considered to be this Brand that allows the consumer to recognize the source of products and services.

Often the Brands can be a name, an element or even a three-dimensional form of a specific product. Due to that, the link between the producer and the consumer is based on the trust that the consumer puts in the Brand, 'the habit typically generates confidence', Mahbobi (1999).

The legal protection under the law of Brands is simply applied to the registered Brands to be protected by two types of legal protections: the civil and the criminal protection. Regarding the civil protection, the legislator stipulated that such protection should be applied once the Brand is duly registered as stipulated by law. The civil protection covers only the registered Brands, while the unregistered Brands are not covered by the civil protection under the law of Brands amendment except for the BrandLogo. As per the criminal protection, it contains four types of crimes: forgery or reproduction of the Brand, the use a forged or reproduced Brands, the use of a Brand owned by others, and the sale or the exhibit of products marked with forged or reproduced Brands belonging to others. The criminal penalty of these crimes was tightened for the amount of the fine by law No. 34 of 1999, Darmish (1998).

For example, to obtain a registered trade mark in the UK, an application must be made to the UK Trade Marks Registry at the IPO. In order to qualify for trade mark protection, the mark must meet certain criteria and must not conflict with prior rights, e.g. pending or registered trademarks.

Many companies look to register their company name or their domain name as their trade mark. For example, both amazon.com and lastminute.com have been registered as trademarks. Having the company name or domain name does not mean that the name will automatically qualify for registration nor that you have an automatic right to register the name as a trade mark, as another company may already have a registered trade mark for that name. For registration, a trade mark must be capable of:

- being represented graphically; and

- Distinguishing the goods or services of one business from those of another, and must not be descriptive.

To pass the first requirement is fairly simple. A brand containing words, designs, letters, numerals, even jingles or sounds will satisfy this test. To pass the second requirement is more difficult. This is particularly true for on-line businesses, as many brands on the internet are chosen by their owners for descriptive reasons. A brand which is not descriptive of your goods and services will be easier to register, as it is more likely to distinguish your goods and services from the goods and services of other businesses.

Brands of famous sports institutions are also subjected to thievery operations either by theft or by reproduction. Some may not realize that such operations have an important economical and commercial dimension. These Brands are exploited by sports institutions to draw financial resources to support their budget and to their overheads in their various activities through allowing the business investment institutions in various fields to place these Brands on a wide variety of miscellaneous products. At the national level, the Engineering Products Company "Olympic" used the logo and name of the Olympic Committee without permission or utilization contract issued from the Olympic Committee. Also, the use of the Logos owned by Sports clubs on different products such as Tshirts or foods products without their permission. The advertizing carried out by a number of coaches and players belonging to sports clubs promoting products without any contracts or commitments binding the production firms with the clubs. This is exactly 
what happened with Al Ahly club coach and some of its players who signed an advertising contract with Etisalaat Phone Company while the club signed a contract with another telecommunication company. The contract stipulated that Al Ahly club will refrain from signing any contracts with any other competitor. At the European level, a shop owner used the English Arsenal Club Logo and placed it on the goods that he used to sell to the public creating an unclear situation for the buyers, if the goods they purchased were genuine or reproduced. Also, Real Madrid Arabic Network Website was prosecuted by the Royal Club (Real Madrid), when its trading name was unfairly used. The website was using the club's logo and a judgment was issued in favor of the Royal Club.

\section{Trade mark infringement}

Your trade mark may be infringed if another sport business uses the same or a similar mark in the course of trade in relation to products and services identical or similar to those for which your mark is registered. If either the mark or the sport products or services in question are only similar, the owner of the mark must satisfy an additional criterion: that the public are likely to confuse the sport products and services of the alleged infringer with the sport products and services of the owner of the trade mark. This requirement can be difficult to satisfy. The class system is important because it allows concurrent use of a mark. A good example is the brand adidas: the sport choose manufacturer and the record label of the same name can exist independently because they each focus on different markets.

If you think that someone is infringing your registered trade mark, you need to be very careful about how you approach the other party, to ensure that you are not seen to be making an unjustified or groundless threat. Ideally, legal advice should be sought before you take any action, as making an allegation of trade mark infringement could result in the other party having a right of action against you for unjustified threats

\section{Previous Studies}

The researchers assessed the studies that carried out on the Logos during the elapsed years. They found that most of Europ studies revealed that European clubs realized substantial income from their Logos. For example the Logo of the Royal Real Madrid Club is the most valuable Logo in the world amount of 462 million Euros in year 2011. UEFA annual report leading over Manchester United, which realized 446 million Euros, followed by Bayern Munich 360 million Euros, and Arsenal Club 257 million Euros a year. Moreover, the researchers compared between European and Arab clubs particularly in the Egyptian clubs. We found that Logos belonging to sports institutions are violated and exploited without any financial return to the owners. So, it should be activated the protective laws for the benefit of Logos owners that will warranty their investments rights to issue permits to other party and agree on the products, that get a financial compensation. This can only be achieved with activation of laws control Brands between the grantor and the granted.

Ala'aEldine Mohamed Ahmed (2006) studied "Legal Protection of Brands in the Special International Law", he found that the acquisition of the internationally Brand protection, gives the right to its owner to use it in any traditional or modern way of variety.

Mahmoud Ahmed Abdel Hamid Mubarak (2006) studied the Brand and the method of its protection accordance with the applied laws in Palestine, he indicated that Brand of unconsidered there is taking a dangerous direction.

El-bishtawi (2008), studied the Franchise contract and its impacts, he recommended the commitment of the grantor to provide 
information to the granted prior to the contractual period and to be bounded to compensate the granted in case that he endures losses in his project resulting from errors of the grantor or from receiving erroneous information given by the grantor.

Awadallah (2008), studied a proposed plan for the protection, marketing and investment of the Brands in sports system, he showed the Brand of the sport system is considered to be the body corporate in front of outside world. The working mechanism for the protection of the Brand will be through the regulations control sports bodies that criminalize the use of the Brands of sports system. Lastly, Abdeen (2011), studied investing Brands in sports marketing, he illustrated that the sport Institutions can produce products bearing its Brand and contract companies to grant them the right to use them. There is a need to issue specific legislation and regulations for sport institutions on how to use the Brand.

Generally the previous studies concluded that, it was noticed that the civil and criminal means of protecting the Brands in sports institutions did not obtain the adequate attention. As well, this study consider as a start for the contribution to close the gap and achieve the benefits of franchise contracts awarded from the grantor to the grantee. Therefore, the researchers address this research aiming to identify the civil and criminal means of protection of Brand name in an attempt to clarify the relationship between the brand owner and the franchisee, the nonoverlapping issues between them, the inviolability of the sports institutions brands, and the activation of the granted protection mechanism in the sport domain which entail the preservation of the rights of both the grantor and grantee in order to realize many of positive effects for both the enterprise and customers.

\section{Research Objectives:}

To identify the civil and criminal Brand protection means of Sports institutions through: The Standards contained in the Rights of Intellectual Property Convention (TRIPS Agreement)

a) The civil protection of the Brands and the Logos in the law (Egypt, Saudi Arabia, England and USA)

b) The criminal protection of the Brands and the Logos in the law (Egyptian and Saudi Arabia)

\section{Research Questions:}

What are the Civil and Criminal Brand Protection Means of Sports Institutions?

\section{Research Procedures}

- Research Methodology: Descriptive scanning approach was used due to the nature of the research

\section{- Research Community:}

- Members of the Egyptian olympic committee

- $\quad$ Board of directors of Egyptian high mass sports federations, and the organizers of most events, festivals and sports tournaments.

- $\quad$ Board members of sport clubs.

Investors, registered in the records of the chamber of commerce in Alexandria, interested in sport through the sponsorship of sports events to promote their products.

\section{Research Sample:}

The research sample is covered most of research community, where about 25 Board Members of Sports Federations (football, handball, basketball, volleyball, swimming); sample of (9) Egyptian Olympic Committee's Members; about 
28 Sports Clubs Board Members (Smouha Club, Sporting Club, Olympy Club, Al Ethaad Club); finally, sample of 25 investors registered in the
Chamber of Commerce in Alexandria, as listed in the following table:

Table (1) Research Sample

\begin{tabular}{|c|c|c|c|}
\hline Research Community & $\begin{array}{c}\text { Research } \\
\text { Community }\end{array}$ & $\begin{array}{c}\text { Survey } \\
\text { sample }\end{array}$ & $\begin{array}{c}\text { Research main } \\
\text { Sample }\end{array}$ \\
\hline Egyptian Olympic Committee's Members & $q$ & $r$ & $v$ \\
\hline Sports Federations Members & $r_{0}$ & 0 & $r \cdot$ \\
\hline Sports Clubs Boards Members & $r^{\prime}$ & $r$ & $r r$ \\
\hline Investors & $r_{0}$ & 0 & $r \cdot$ \\
\hline Total & N & $1 /$ & $r 9$ \\
\hline
\end{tabular}

\section{Tools of Data collection:}

The main approach used by the researchers is to design questionnaire. The design is based on survey covering, theoretical studies, the scientific researches and the related references. The axes of the questionnaire were identified according to the study objectives. The terminology used in the phrases of the questionnaires was defined. The primary questionnaire was assessed by ten specialized experts in sport management; identified the appropriate axes of the research, the connection between the phrases of each axis, the adequacy, and the comprehensiveness and objectivity link of the questionnaire's phrases. According to the assessment of the experts, the percentage agreement of the experts in regards to the questionnaire was constrained between 95 to $100 \%$. The researchers compiled the final questionnaire, which consisted of two main axes titles: Civil Protection of the Brand and Criminal Protection of the Brand in Sports Institutions.

\section{I: Scientific Variables of the questionnaire:}

The confidence level of the questionnaires was determined in two ways:

a) Contents Validation: The researchers were depending on the experts' trustfulness in order to identify the suitability of the axes titles, the phrases and their clearness. A number of phrases were deleted and, others were modified in accordance with expert's assessment.

b) Internal Coherence Validation: The internal coherence validation was calculated by determining the correlation coefficients between the phrases and the grand total of the axis to which they belong (i.e. between the phrase degree and the grand total of the phrases of the axis to which it belongs).

Index correlation coefficient value at the degree of freedom (28) and the function level $(0.05)=$ 0.254 and at the degree of freedom (60) and level $(0.01)=0.330$.

The correlation coefficient between each phrase and axis degree to which it belongs was calculated. 
Table (2): Correlation coefficient between each phrase and axis degree to which it belongs $(n=15)$

\begin{tabular}{|c|c|c|c|c|c|c|c|}
\hline Phrase No & $\begin{array}{c}\text { Correl. } \\
\text { Coef. }\end{array}$ & $\begin{array}{c}\text { Phrase } \\
\text { No }\end{array}$ & $\begin{array}{c}\text { Correl. } \\
\text { Coef. }\end{array}$ & $\begin{array}{c}\text { Phrase } \\
\text { No }\end{array}$ & $\begin{array}{c}\text { Correl. } \\
\text { Coef. }\end{array}$ & $\begin{array}{c}\text { Phrase } \\
\text { No }\end{array}$ & $\begin{array}{c}\text { Correl. } \\
\text { Coef. }\end{array}$ \\
\hline \multicolumn{2}{|c|}{ First axis } & & & \multicolumn{2}{|c|}{ Second axis } & & \\
\hline 1 & אזד. & 10 & אזד. & $r q$ & . VTr & $\varepsilon r$ & . Tor \\
\hline$r$ & $\because v \cdot l$ & 17 &. Vor & $r$. & $\cdot V \leq r$ & $\varepsilon \varepsilon$ & .099 \\
\hline$r$ & .710 & iv & .017 & r & $\because v 1$. & $\leqslant 0$ & . \\
\hline$\varepsilon$ & . & 11 & . & $r r$ & .817 & $\leq 7$ & .819 \\
\hline - & VYYT & 19 &.$V Y T$ & rr & $.0 \vee 9$ & $\leqslant V$ & $\because V Y Y$ \\
\hline 7 & .710 & $r$. & .719 & $r \leq$ &.$\leqslant 1 V$ & $\leqslant \Lambda$ & $.79 \leq$ \\
\hline V & $.7 \wedge \varepsilon$ & $r$ & $\because V Y \leq$ & ro & $\cdot .7 \cdot V$ & $\leqslant 9$ & $\because V$ \\
\hline$\wedge$ & $\because v \cdot 9$ & rr & $\because \vee 19$ & m & .0 .1 & 0 . & $\because \vee \mu \wedge$ \\
\hline 9 & . 749 & Yr & $\cdot \vee 19$ & $r v$ & $.0 \leq r$ & & \\
\hline 1. & $\cdot V \backslash 1$ & $Y \leq$ & .017 & $r \Lambda$ & $\cdot r \wedge \uparrow$ & & \\
\hline 11 & $.79 \leq$ & ro & $\cdot V T r$ & $r q$ &. .507 & & \\
\hline ir & . & ry & $.79 \leq$ & $\varepsilon$ & .011 & & \\
\hline ir & $\because \times 10$ & $r V$ & .749 & $\leqslant 1$ & $.79 \mathrm{~V}$ & & \\
\hline $1 \varepsilon$ & $\because \vee \backslash \wedge$ & $r \wedge$ & $.70 \mathrm{r}$ & $\leqslant r$ & .094 & & \\
\hline
\end{tabular}

* Coef. Correl. $=$ Coefficient of Correlation

II: Statistical Consistency: The two applications was calculated to be highly statisticalconsistency was measured by the significant, 0.912.

following two ways:

a) Re-application the questionnaire: the questionnaire was reapplied by fifteen individual randomly selected out of the original research community and after fifteen days. The correlation coefficient between the results of the b) Calculation of consistency according to Cronbach Alfa approach.

c) Cronbach Alfa factor: For the fact that Alpha Cronbach equation takes into account the disparity of each phrase and the variation of the form.

Table (3): Shows the consistency using the re-application and Cronbach Alfa approaches. Phr \# = Phrase Number, a Cons Coef $=$ Alfa Consistance Coefficient, Cor. Coef. $=$ Coefficient of correlation

$(n=15)$

\begin{tabular}{|c|c|c|c|c|c|c|c|c|c|c|c|}
\hline \multicolumn{6}{|c|}{ Civil protection of the brand in the sports institutions } & \multicolumn{6}{|c|}{$\begin{array}{l}\text { Criminal protection of the brand in the sports } \\
\text { institutions }\end{array}$} \\
\hline $\begin{array}{c}\text { Phr } \\
\#\end{array}$ & $\begin{array}{c}\alpha \\
\text { ConsCoef }\end{array}$ & $\begin{array}{l}\text { Cor. } \\
\text { Coef }\end{array}$ & $\begin{array}{c}\text { Phr } \\
\#\end{array}$ & $\begin{array}{c}\alpha \\
\text { ConsCoef }\end{array}$ & $\begin{array}{l}\text { Cor. } \\
\text { Coef }\end{array}$ & $\begin{array}{c}\text { Phr } \\
\#\end{array}$ & $\begin{array}{c}\alpha \\
\text { ConsCoef }\end{array}$ & $\begin{array}{l}\text { Cor. } \\
\text { Coef }\end{array}$ & $\begin{array}{c}\text { Phr } \\
\#\end{array}$ & $\begin{array}{c}\alpha \\
\text { ConsCoef }\end{array}$ & $\begin{array}{l}\text { Cor. } \\
\text { Coef }\end{array}$ \\
\hline 1 & $\because \vee \vee T$ & $\cdot.\rceil \wedge \varepsilon$ & $1 \varepsilon$ & $\because \vee \vee \wedge$ & $.0 \wedge \leqslant$ & YY & $\cdot \wedge .0$ & $\cdot 7 \cdot 1$ & $r q$ & .019 & $.7 T \wedge$ \\
\hline$r$ & $\because \vee \vee \wedge$ & $\because V \backslash Y$ & 10 & $\because \vee \wedge \varepsilon$ & .071 & $r V$ & $\because 197$ & $\because 0 \wedge 1$ & $\varepsilon$ & $\because \vee Y \wedge$ & $.7 T V$ \\
\hline$r$ & $\because V V Y$ & $.7 \leqslant 0$ & 17 &.$V V T$ & $.0 \vee \leqslant$ & $r \wedge$ & $\because \vee \wedge I$ & .071 & \&1 & $\cdot V T \leq$ & . $7 \ldots$ \\
\hline$\varepsilon$ &.$V \vee V$ & י & 18 & $\because V \wedge r$ & $.09 \varepsilon$ & rq & $\because \vee \vee \varepsilon$ & $.7 \wedge 1$ & $\varepsilon r$ & .791 & $\cdot 7 \cdot 1$ \\
\hline 0 & $\because \vee \vee O$ & $.09 \leq$ & 11 & $\because \vee \wedge \varepsilon$ & $.0 \leq 7$ & $r$. & $\because \vee \vee \&$ & $.0 \leqslant 9$ & $\varepsilon r$ & $.79 r$ & .711 \\
\hline
\end{tabular}




\begin{tabular}{|c|c|c|c|c|c|c|c|c|c|c|c|}
\hline \multicolumn{6}{|c|}{ Civil protection of the brand in the sports institutions } & \multicolumn{6}{|c|}{$\begin{array}{l}\text { Criminal protection of the brand in the sports } \\
\text { institutions }\end{array}$} \\
\hline $\begin{array}{c}\text { Phr } \\
\#\end{array}$ & $\begin{array}{c}\alpha \\
\text { ConsCoef }\end{array}$ & $\begin{array}{l}\text { Cor. } \\
\text { Coef }\end{array}$ & $\begin{array}{c}\text { Phr } \\
\#\end{array}$ & $\begin{array}{c}\alpha \\
\text { ConsCoef }\end{array}$ & $\begin{array}{l}\text { Cor. } \\
\text { Coef }\end{array}$ & $\begin{array}{c}\text { Phr } \\
\#\end{array}$ & $\begin{array}{c}\alpha \\
\text { ConsCoef }\end{array}$ & $\begin{array}{l}\text { Cor. } \\
\text { Coef }\end{array}$ & $\begin{array}{c}\text { Phr } \\
\#\end{array}$ & $\begin{array}{c}\alpha \\
\text { ConsCoef }\end{array}$ & $\begin{array}{l}\text { Cor. } \\
\text { Coef }\end{array}$ \\
\hline 7 & $\because \vee \wedge \varepsilon$ & $\because 0 \leqslant V$ & 19 & $\because V V T$ & $\because 09$. & $\mu_{1}$ & $\because \vee \wedge r$ & ( וTI & $\varepsilon \varepsilon$ & $\because v \cdot q$ & ह \\
\hline $\mathrm{V}$ & $\because V V \mu$ & $.0 Y A$ & $r$. & $\because V \wedge r$ & $.0 \mathrm{VI}$ & rr & $\because \vee 9 \leq$ &.$O V Y$ & $\leqslant 0$ & $\because .807$ & .099 \\
\hline$\Lambda$ & $\cdot V \wedge r$ & $.07 \leqslant$ & $r 1$ & $\cdot V 7 \leq$ & . Or. & $r \mu$ & .VAr & $. V T \leq$ & $\leqslant 7$ &.$V T^{\prime}$ & $.7 \pi V$ \\
\hline 9 & $\because \vee Y \leq$ & .041 & Yr & .170 & .OY. & $r \leq$ & $\because \vee \vee \leq$ & .711 & $\varepsilon V$ & $\because \vee 19$ & .701 \\
\hline 1. & $\because 1770$ & .011 & $r r$ & .791 & $.71 \wedge$ & ro & $\because 190$ & סז7. & $\varepsilon \wedge$ & $\cdot v \leqslant r$ & $.7 \pi q$ \\
\hline 11 & $\because \vee \vee \leqslant$ & . & $r \varepsilon$ & $.7 \vee 7$ & .711 & rq & $\because \vee \vee q$ & $\cdot T V \varepsilon$ & $\varepsilon q$ & UYY & .7 .0 \\
\hline Ir & $\because \vee \vee \wedge$ & $.0 \leq 1$ & ro & $\because V T r$ & & $r v$ & $\because V \wedge r$ & & 0. & $\because V Y \wedge$ & \\
\hline $1 r$ & $\because \vee \wedge \uparrow$ & .000 & & & & $\mu \wedge$ & $\because \vee q \vee$ & & & & \\
\hline
\end{tabular}

The value of the coefficient of correlation index at $(0.01)=$ and at $(0.05)=$

It is clear from table (3) that the phrases form. As it can be seen, the values of the consistency coefficients values of the form's coefficient of correlation using the reaxes are acceptable and are less than or equal to application approach are the values of the the coefficient of the axis consistence to which coefficient at level $(0.01,0.05)$ indicating the the phrase belongs, it means that the deletion of consistency of the form. any phrase will have a negative effect on the

Table (4): Consistency coefficients of the two axes of the questionnaire and the overall consistency coefficient

\begin{tabular}{|c|c|}
\hline Phrase Number & Consistency coefficient \\
\hline Civil protection of the brand in the sports institutions & $\cdot \vee \wedge \wedge$ \\
\hline Criminal protection of the brand in the sports institutions & $\ddots \wedge .0$ \\
\hline Total Degree & $\ddots \wedge / 1$ \\
\hline
\end{tabular}

Table (4) showed that the values of the coefficients of consistency of the phrases of the questionnaire are of acceptable values (greater than 0.7 ) and the value of the coefficient of consistency of each axis is greater than or equal to the coefficient of consistency of any of the phrases of that axis to which it belongs, and the value of the coefficient of consistency of the form is $(0.811)$. 
Table (5): Percentage and K2 value for search sample responses on first axis phrases "Civil protection of the brand in the sports institutions"

\begin{tabular}{|c|c|c|c|c|c|c|c|c|c|c|}
\hline \multirow{3}{*}{$\mathrm{Sr}$} & \multirow{3}{*}{ The Phrase } & \multicolumn{4}{|c|}{ Senior Management $=49$} & \multicolumn{4}{|c|}{ Investors $\mathbf{n}=\mathbf{2 0}$} & \multirow{3}{*}{$\mathbf{K}^{2}$} \\
\hline & & \multicolumn{2}{|c|}{ Agree } & \multicolumn{2}{|c|}{ Disagree } & \multicolumn{2}{|c|}{ Agree } & \multicolumn{2}{|c|}{ Disagree } & \\
\hline & & $\mathbf{n}$ & $\%$ & $\mathbf{n}$ & $\%$ & $\mathbf{n}$ & $\%$ & $\mathbf{n}$ & $\%$ & \\
\hline \multicolumn{11}{|c|}{ Article (10 Bis) of Paris Convention for such Protection included: } \\
\hline 1 & $\begin{array}{l}\text { Prohibition of any acts of nature that } \\
\text { may create any mean of confusion with } \\
\text { other competitors, their products or } \\
\text { their various activities. }\end{array}$ & $\varepsilon$. & אוד & 9 & IN.rV & 19 & $90 .$. & 1 & $0 . \cdots$ & ${ }^{*} r_{.} .0$ \\
\hline r & $\begin{array}{l}\text { Untruthful allegations whose nature } \\
\text { will create distrust toward the } \\
\text { establishment of other competitors, } \\
\text { their products or their various } \\
\text { activities. }\end{array}$ & rq & 19.09 & 1. & $r \cdot . \leqslant 1$ & r. & $1 \ldots$ & . & $\because \cdots$ & ${ }^{* *} \varepsilon . \vee V$ \\
\hline r & $\begin{array}{l}\text { Use of statements or allegations that } \\
\text { would mislead the public as to their } \\
\text { nature or the production method or } \\
\text { sport services. }\end{array}$ & $\leqslant 0$ & $91 . \wedge \leq$ & $\varepsilon$ & 1.17 & 11 & $9 . .$. & r & $1 \cdot \cdot$ & $\because 7$ \\
\hline$\varepsilon$ & $\begin{array}{l}\text { The use of the Brand owned by third } \\
\text { parties or other sporting establishment } \\
\text { or its reproduction is considered as acts } \\
\text { that create confusion, and in } \\
\text { distinctness for the products or } \\
\text { services. }\end{array}$ & $\varepsilon \lambda$ & $9 \vee .97$ & 1 & $r \cdot \varepsilon$ & 17 & $\Lambda \cdot . \cdot$ & $\varepsilon$ & $r \cdot \cdot$ & $\left.{ }^{* *}\right\urcorner . \wedge \mathrm{r}$ \\
\hline \multicolumn{11}{|c|}{ * Civil protection of the Brand in the Egyptian Law. } \\
\hline 0 & $\begin{array}{l}\text { Article }(66 / 1) \text { of the Trade Act No. } 17 \\
\text { of } 1999 \text { stipulates that any act contrary } \\
\text { to custom and principals observed in } \\
\text { business transactions is considered as } \\
\text { illegal competition. This also includes } \\
\text { the exploitation of others commercial } \\
\text { name, patents, secrets or leaving the } \\
\text { job. }\end{array}$ & $\leq 9$ & $1 \ldots$ & · & $\because \cdots$ & 19 & $90 .$. & 1 & $0 . \cdots$ & ${ }^{*} r_{.} \leqslant q$ \\
\hline & \multicolumn{10}{|l|}{ * Civic Protection of the Brand in England } \\
\hline 7 & $\begin{array}{l}\text { The Civic Protection of the Brand is } \\
\text { according with the public law in } \\
\text { England and is based on illegal } \\
\text { competition. }\end{array}$ & $\varepsilon$ & Nו. & 9 & IN.rV & 17 & $\wedge \cdot \cdots$ & $\varepsilon$ & $r \cdot \cdot$ & $\because \cdot r$ \\
\hline v & $\begin{array}{l}\text { The trade practitioner using fraudulent } \\
\text { methods to attract more users to the } \\
\text { product, service or activity which } \\
\text { harms the institution or just likelihood. }\end{array}$ & $\leqslant 7$ & $9 \longleftarrow . \wedge 1$ & $r$ & 7.14 & 11 & $9 \cdot \ldots$ & r & $1 \cdot \cdot$ & $\cdot r t$ \\
\hline & \multicolumn{10}{|l|}{ * Civic Protection of the Brand in USA } \\
\hline$\wedge$ & $\begin{array}{l}\text { The civic prosecution is the effective } \\
\text { mean for the purpose of protecting the } \\
\text { Brand }\end{array}$ & $\leqslant 9$ & $1 \cdots \cdots$ & · & $\because \cdots$ & 11 & $9 . .$. & r & $1 \cdot \cdot$ & ${ }^{* *} 0.0$ \\
\hline 9 & $\begin{array}{l}\text { It is carried out through the owner of } \\
\text { the Brand or his Deputy by instituting a } \\
\text { civil action. US courts compensate the } \\
\text { Brand owner for the direct or indirect } \\
\text { losses resulting from the violation of } \\
\text { his rights. }\end{array}$ & $\leqslant 7$ & $9 \Gamma . \wedge 1$ & $r$ & 7.11 & 17 & $\Lambda \cdot .$. & $\varepsilon$ & $r \cdot \cdots$ & 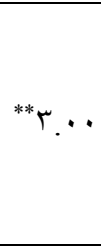 \\
\hline 1. & $\begin{array}{l}\text { Persons affected by an act of unfair } \\
\text { competition have the right to sue for }\end{array}$ & $\leqslant V$ & 90.94 & r & $\varepsilon .1$ & 11 & $9 . .$. & r & $1 \cdot \cdot$ & $\cdot .91$ \\
\hline
\end{tabular}




\begin{tabular}{|c|c|c|c|c|c|c|c|c|c|c|}
\hline & $\begin{array}{l}\text { damages, whether damages are material } \\
\text { or moral }\end{array}$ & & & & & & & & & \\
\hline 11 & $\begin{array}{l}\text { In accordance with the General rules, } \\
\text { the burden of proving harm falls on the } \\
\text { compensation requester for the } \\
\text { wrongful act. }\end{array}$ & $\leq 9$ & $1 \cdots \cdot$ & . & $\because \cdot$ & 11 & $9 \cdot .$. & r & $1 \cdot \cdot$ & ${ }^{* *} 0.0$ \\
\hline Kr & $\begin{array}{l}\text { The violation would create confusion in } \\
\text { the store, its products, discredit the } \\
\text { owners or its managers, the product, } \\
\text { the service or activity. }\end{array}$ & $\leqslant 0$ & $१ १ . \wedge \varepsilon$ & $\varepsilon$ & 1.17 & IV & 10... & $r$ & 10. & $\cdot . \mathrm{VT}$ \\
\hline ir & $\begin{array}{l}\text { Under the Act, the law authorized the } \\
\text { victim of unfair competition to lawsuit } \\
\text { against the aggressor requesting } \\
\text { prevention of violation and asks for } \\
\text { compensation for damage. In addition } \\
\text { to that, the potential publication of the } \\
\text { judgment in a daily newspaper at the } \\
\text { expense of the convicted offender is } \\
\text { possible. }\end{array}$ & $\leqslant 9$ & $1 \cdots \cdot$ & . & $\because \cdots$ & 19 & $90 .$. & 1 & $0 .$. & ${ }^{*}$ ५. $\leqslant q$ \\
\hline $1 \leqslant$ & $\begin{array}{l}\text { The legal owner of the Brand has the } \\
\text { right to legal protection on the basis of } \\
\text { unfair competition, whether the Brand } \\
\text { is or is not registered, in case that the } \\
\text { Brand is unregistered the protection is } \\
\text { considered on the basis of unfair } \\
\text { competition. }\end{array}$ & $\varepsilon v$ & 90.94 & r & $\varepsilon . \wedge$ & 17 & $\wedge \cdot .$. & $\varepsilon$ & $r \cdot$. & * \\
\hline 10 & $\begin{array}{l}\text { In case that the Brand is registered } \\
\text { under the special criminal protection } \\
\text { prescribed in the intellectual property } \\
\text { rights protection Act No. } 82 \text { of } 2002 \\
\text { the Brand owner has the right to } \\
\text { compensation, whether in criminal or } \\
\text { other courts. }\end{array}$ & $\leqslant 9$ & $1 \cdots \cdot$ & . & $\because \cdots$ & 11 & $9 \cdot .$. & r & $1 \cdot \cdot$ & ${ }^{* *} 0.0$ \\
\hline & \multicolumn{10}{|l|}{ * Civil Protection for Famous Logo } \\
\hline 17 & $\begin{array}{l}\text { The Famous Logo is the logo known } \\
\text { over time and coexisted with } \\
\text { generations such as Al-Ahly, Al } \\
\text { Zamalek, Al Itihad Al Sakandary Al } \\
\text { Ismaily Logos and other prestigious } \\
\text { sporting institutions Logos }\end{array}$ & $\leqslant 9$ & $1 \cdots \cdots$ & . & $\because \cdots$ & 19 & $90 .$. & 1 & $0 .$. & ${ }^{*} \varphi_{.} \leqslant 9$ \\
\hline iv & $\begin{array}{l}\text { Under article (6 II) of Paris agreement } \\
\text { for the protection of Famous Logos } \\
\text { even if unregistered, States members } \\
\text { of the Union are committed to reject } \\
\text { the application for registration of the } \\
\text { Logo, invalidate its registration or } \\
\text { prohibit its use unless the registration } \\
\text { application is submitted by the owner } \\
\text { of the Famous Logo in person or with } \\
\text { his consent }\end{array}$ & $\varepsilon$. & ז'.11 & 9 & $|\Lambda, r\rangle$ & 10 & vo... & 0 & ro. & $\cdot r q$ \\
\hline 11 & $\begin{array}{l}\text { The protection accorded to Famous } \\
\text { Logo does not arise from its } \\
\text { registration or use, but arises from been } \\
\text { commonly fame in the State where it } \\
\text { needs to be protected. }\end{array}$ & $\varepsilon r$ & 10.11 & v & $1 \leqslant . r 9$ & 10 & vo... & 0 & ro. & 1.14 \\
\hline & \multicolumn{10}{|c|}{$\begin{array}{l}\text { Article (16) of the TRIPS agreement promotes and supports the traditional protection of Famous Logos } \\
\text { contained in the Paris agreement in terms of expansion of the concept of Famous Brand protection to include }\end{array}$} \\
\hline 19 & $\begin{array}{l}\text { The development of a general criterion } \\
\text { that allows the WTO Member States to } \\
\text { define the concept of Famous Logo } \\
\text { guideline. }\end{array}$ & $\leqslant \wedge$ & $9 \vee .97$ & 1 & $r_{.} \cdot \varepsilon$ & iv & $10 .$. & $r$ & 10. & ${ }^{*} \leqslant, r V$ \\
\hline
\end{tabular}




\begin{tabular}{|c|c|c|c|c|c|c|c|c|c|c|}
\hline & \multicolumn{10}{|c|}{$\begin{array}{l}\text { Article (16) of the TRIPS agreement prohibited the use of the Famous Logo if registered on goods or services } \\
\text { non-identical to the goods or services that use the Logo in their distinctiveness if two conditions are available: }\end{array}$} \\
\hline r. & $\begin{array}{l}\text { That the usage of the Famous Logo on } \\
\text { non-identical goods or services leads to } \\
\text { believe in the existence of a link } \\
\text { between those non-identical goods or } \\
\text { services and the registered Logo owner. }\end{array}$ & $\leqslant V$ & 90.94 & r & $\varepsilon .1$ & 17 & $\wedge \cdot .$. & $\varepsilon$ & $r \cdot . \cdot$ & * \\
\hline r) & $\begin{array}{l}\text { That the usage of the Logo on non- } \\
\text { identical goods leads to the possibility } \\
\text { of prejudice to the interests of the Logo } \\
\text { owner and subjects him to damage. }\end{array}$ & $\leqslant 7$ & $9 \Gamma . \wedge 1$ & $r$ & 7.14 & 10 & vo... & 0 & ro. & ${ }^{* *} \leqslant .9 \leqslant$ \\
\hline & \multicolumn{10}{|c|}{ * Civil protection of the Famous Logo in the Egyptian law } \\
\hline rr & $\begin{array}{l}\text { Article } 68 \text { of the Egyptian law } \\
\text { stipulates that, "the owner of the } \\
\text { Internationally registered Famous Logo } \\
\text { will have in the Arab Republic of } \\
\text { Egypt the legal protection even if } \\
\text { unregistered in Egypt". }\end{array}$ & $\leq 9$ & $1 \cdots \cdot$ & . & $\because \cdots$ & 11 & $9 \cdot . \cdot$ & r & $1 \cdot \cdot$ & ${ }^{* *} 0.0$ \\
\hline rT & $\begin{array}{l}\text { In the previous case, the registry } \\
\text { agency shall refuse ex officio any } \\
\text { application for registration of identical } \\
\text { Logo that including its use to } \\
\text { distinguish similar products used by the } \\
\text { Famous Logo products, unless the } \\
\text { application is submitted by the Famous } \\
\text { Logo owner. }\end{array}$ & $\leqslant 9$ & $1 \cdots \cdot$ & . & $\because \cdots$ & 19 & $90 . .$. & 1 & $0 . \cdots$ & ${ }^{*} r . \leqslant 9$ \\
\hline$r \leq$ & $\begin{array}{l}\text { The above verdict applies to } \\
\text { registration applications focused on } \\
\text { products that are not identical to the } \\
\text { Famous Logo products in case that the } \\
\text { Famous Logo is registered in one of the } \\
\text { World Trade Institution member States } \\
\text { and the Arab Republic of Egypt }\end{array}$ & $\varepsilon \wedge$ & $9 \vee .97$ & 1 & 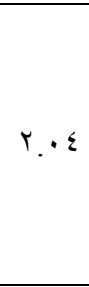 & IV & $10 . .$. & $r$ & 10. & $*$ * $r v$ \\
\hline ro & $\begin{array}{l}\text { The recognition of the Egyptian } \\
\text { legislature's of internationally } \\
\text { recognized Famous Logo and will } \\
\text { benefit in the Arab Republic of Egypt } \\
\text { by the same protection of the registered } \\
\text { mark in the Arab Republic of Egypt, } \\
\text { even if this Famous Logo is } \\
\text { unregistered in Egypt }\end{array}$ & $\leqslant 7$ & $9 T . \wedge \wedge$ & $r$ & 7.14 & 17 & $\wedge . .$. & $\varepsilon$ & $r \cdot$. & ${ }^{* *}$ ץ.. \\
\hline
\end{tabular}

" $n$ " at the function level $(0.01)=2.617$ and at $(0.05)=2$

Table (5) shows that the computed values of $\mathrm{K}^{2}$ for the differences between the responses of the sample to the phrases of the first axe "Civil protection of the brand in the sports institutions" exceed the $\mathrm{T}$ for Chi-Square at a level of index (0.01) signifying the consent of all members of the sample in regards to the content of the phrases of the axis. All the opinions of the research sample agreed on the content of the phrases $(1,2,3,4)$ with a consent percentage ranging from 79.59 to $100 \%$. The context of article (10 ii) of the Paris agreement stating that the civil protection of the Logo include: the prohibition of acts that create confusion with other institutions, products or activities belonging to competitors, in addition to untruthful allegations of whose nature would mislead the public, as well as the use of the Brand owned by third parties or other sport institution, and that is considered to be works that create confusion and indistinctness between products or services.

The civil protection of the brand listed by the Egyptian law stipulates that "any act contrary to custom and principals observed in business transactions is considered as illegal competition. 
This also includes the exploitation of others commercial name, patents, secrets or leaving the job". In this regard, Abeer (2006) emphasized that in management language Brand is known as cumulative property whose value can grow and develop without any costs or expenses to become one of the greatest estates or assets of the Institution and of great importance, perhaps greater than the product itself. As for the phrases $(6,7)$ concerning the civil protection in England, the research sample agreed with an approval percentage ranging (from 81 to $93 \%$ ) on the protection in accordance with the public law on the base of the illegal competition of trade practitioner using fraudulent methods to attract more users to the product, service or activity which harms the institution.

Concerning to the civil Protection, if USA the opinion of the research sample agreed on the phrases $(9,10,11,12,13,14,15)$ with a percentage ranging from 91 to $100 \%$. So that the civic prosecution is the effective mean for the purpose of protecting the Brand name and is carried out through the owner or his deputy by instituting a civil action and US courts compensate the Brand owner for the direct or indirect losses resulting from the violation of his rights. If the Brand is registered under the special criminal protection prescribed in the intellectual property rights protection Act No. 82 of 2002 the Brand owner has the right to compensation, whether in criminal or other courts.

In this regard Abdul Aziz Abu Nab'aa (2002) recalls that the Brands possess a massive importance as they help in building a loyal audience, help to distinguish the product from similar ones in the market and facilitate communication between the institution and recipient, Abu Nabaa (2002).

In-addition, Fahd S. Al-Khatib and Mohammed S. Awad (2000), mentioned that the Brand provides a legal protection to sport product and enable the institution to regulate purchases by
Brand, it helps to divide the market and provide an impression of a good picture of the institution among the recipients. As per the Famous Logo, the opinion of the research sample agreed on the phrases from 16 through 25 with a consent percentage ranging from 81 to $100 \%$ on the content of article (6 II) of Paris agreement for the Protection of the Famous Logo even if unregistered, States members of the Union are committed to reject the application for registration of the Logo or invalidate its registration or prohibit its use unless the registration application is submitted by the owner of the famous logo in person or with his consent, so the protection accorded to famous logo does not arise from its registration or use, but arises from been commonly fame in the State where it needs to be protected. Article (16) of the TRIPS agreement promotes and supports the traditional protection of Famous Logos contained in the Paris agreement in terms of expansion of the concept of Famous Logo protection to include the Service Logo and the development a general criterion that allows the WTO Member States to define the concept of Famous Logo guideline. The Egyptian law for the Civil Protection of the Logo stipulated that "the owner of the Internationally registered Famous Logo will have in the Arab Republic of Egypt the legal protection even if unregistered in Egypt" and that the registry agency shall refuse ex officio any application for registration of identical Logo that including its use to distinguish similar products used by the Famous Logo products, unless the application is submitted by the Famous Logo owner. Also the recognition of the Egyptian legislature's of internationally recognized Famous Logo and will benefit in the Arab Republic of Egypt by the same protection of the registered mark in the Arab Republic of Egypt, even if this Famous Logo unregistered in Egypt. In this regard, the results of Lin's et al., (2000) confirm that the Brand and the good reputation of the institution is an effective means to link the product and the 
recipients, as well as between the recipients and the institution providing the service, Lin et al., (2000).

AmerAlkeswani (1998), underlined that the Brand is considered famous if its usage by its owner is extended over time and that the frequency of its acquirement by the product users increases and so become known to the majority of recipients. As stated in the Paris Agreement, the protection accorded to the Famous Logo does not arise from its registration or use, but arise from simply being well-known in the State where it is requested to be protected even if unregistered. This means that it is sufficient to consider that the Logo is famous that it needs to be widely known through publicity campaigns and advertisement without requiring that products bearing the Logo have been marketed in that State, Abdel-Kareem (2007).

The researchers pointed that the production of more than one product under the name of an institution may affect the products domain. This will contribute in the strength of the Logo for producing institutions pending on its seniority in the market, for example Pepsi drinks Co. generated several Brands such as 7-Up and Miranda. But in the sport domain, the sport club may participate in just one activity such as football and achieve gains that will saturate the needs of his masses and through that he contribute in strengthening the Logo of this Club and that will be of great benefit. Contrarily to that, another Club practicing several sports activities, but does not realize any achievements particularly in football; therefore his Logo does not gain trade strength.

Table (6): Percentage and K2 value for search sample responses on first axis phrases of "Criminal protection of the brand in the sports institutions"

$N(69)$

\begin{tabular}{|c|c|c|c|c|c|c|c|c|c|c|}
\hline \multirow{3}{*}{$\mathrm{Sr}$} & \multirow{3}{*}{ The Phrase } & \multicolumn{4}{|c|}{ Senior Management $=49$} & \multicolumn{4}{|c|}{ Investors $\mathbf{n}=\mathbf{2 0}$} & \multirow{3}{*}{$\mathbf{K a}^{2}$} \\
\hline & & \multicolumn{2}{|c|}{ Agree } & \multicolumn{2}{|c|}{ Disagree } & \multicolumn{2}{|c|}{ Agree } & \multicolumn{2}{|c|}{ Disagree } & \\
\hline & & $\mathbf{n}$ & $\%$ & $\mathbf{n}$ & $\%$ & $\mathbf{n}$ & $\%$ & $\mathbf{n}$ & $\%$ & \\
\hline Y & $\begin{array}{l}\text { Article (16) of the TRIPS agreement } \\
\text { stipulates on the commitment of Member } \\
\text { States to apply at least the procedures and } \\
\text { the criminal penalties in cases of the } \\
\text { registered Brands deliberate reproduction } \\
\text { or copyright theft on a commercial scale. }\end{array}$ & $\leqslant 9$ & $1 \cdots$ & . & $\because \cdot$ & 11 & $9 .$. & r & $1 \cdot$ & $\begin{array}{l}* 0.0 \\
*\end{array}$ \\
\hline rV & $\begin{array}{l}\text { As stipulated in article (61) of the TRIPS } \\
\text { agreement, imposed sanctions could } \\
\text { include "imprisonment or fines" - } \\
\text { enough to provide sanctions } \\
\text { commensurate with the level of the } \\
\text { penalties applied for crimes of } \\
\text { comparable gravity and in appropriate } \\
\text { cases. }\end{array}$ & ro & $v 1 . \leqslant r$ & $1 \leq$ & YA.OV & 17 & $\wedge \cdot$. & $\varepsilon$ & $r \cdot{ }^{*}$ & $.0 \leqslant$ \\
\hline$r \wedge$ & $\begin{array}{l}\text { Imposed sanctions may include also } \\
\text { sequestration of infringed goods and any } \\
\text { equipment mainly used in the offence to } \\
\text { be confiscated and destroyed. }\end{array}$ & $\leqslant \vee$ & 90.94 & $r$ & $\varepsilon .1$ & 11 & $9 \cdot$. & r & $1 \cdot \cdot$ & .91 \\
\hline rq & $\begin{array}{l}\text { Countries member in TRIPS agreement } \\
\text { may impose the procedures and the }\end{array}$ & $\leqslant 7$ & 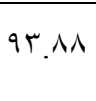 & r & 7.14 & 10 & vo. & 0 & ro. & $\begin{array}{c}* \varepsilon .9 \leq \\
*\end{array}$ \\
\hline
\end{tabular}




\begin{tabular}{|c|c|c|c|c|c|c|c|c|c|c|}
\hline & $\begin{array}{l}\text { criminal penalties in other cases of } \\
\text { infringement of intellectual property } \\
\text { rights, especially where it is deliberately } \\
\text { modified and on a commercial scale }\end{array}$ & & & & & & & & & \\
\hline & \multicolumn{10}{|c|}{ * The criminal protection of the brand in the Egyptian law: } \\
\hline & \multicolumn{10}{|c|}{ The law No. (82) of the 2002 on the protection of intellectual property rights: warmed about } \\
\hline r. & Offences against patents & $\leqslant \wedge$ & $9 \vee .97$ & 1 & $r . \varepsilon$ & r. & $\cdots$ & · & $\because \cdots$ & $\cdot \leqslant 1$ \\
\hline 蒋 & Offences against designs & $\varepsilon \wedge$ & $9 \vee .97$ & 1 & $r . \varepsilon$ & r. & $\cdots$ & · & $\because \cdots$ & $\cdot \varepsilon 1$ \\
\hline rt & Offences against undisclosed information. & $\varepsilon$. & 1). & 9 & IN.rV & 17 & A.. & $\varepsilon$ & $\begin{array}{r}r \cdot \cdot \\
\cdot\end{array}$ & $\because \cdot r$ \\
\hline זr & $\begin{array}{l}\text { Crimes on Brands, trading data, } \\
\text { geographical indicators, and industrial } \\
\text { designs and industrial models. }\end{array}$ & $\leqslant V$ & 90.94 & r & $\varepsilon \cdot \wedge$ & r. & $\cdots$ & · & $\because \cdots$ & $\cdot \wedge \varepsilon$ \\
\hline$r \leqslant$ & $\begin{array}{l}\text { Offences crimes against copyrights and } \\
\text { neighboring rights and offences against } \\
\text { property rights in plant varieties. }\end{array}$ & $\leqslant \wedge$ & $9 \vee .97$ & 1 & $r . \varepsilon$ & $r \cdot$ & $1 \cdots$ & · & $\because \cdots$ & $\because \leqslant 1$ \\
\hline ro & $\begin{array}{l}\text { Article (61) of the TRIPS agreement } \\
\text { stipulated on certain penalties ranging } \\
\text { from imprisonment and a fine or both. }\end{array}$ & $\leqslant 7$ & $94 . \wedge 1$ & $r$ & 7.11 & $1 \varepsilon$ & $v_{\bullet} \cdot$ & 7 & $r \cdot$. & $\begin{array}{l}* V .1 \varepsilon \\
*\end{array}$ \\
\hline דו & $\begin{array}{l}\text { The Egyptian legislature allowed when } \\
\text { convicted the judgment may require the } \\
\text { closure of the institution that the } \\
\text { sentenced exploited for committing the } \\
\text { crime for a term not exceeding six } \\
\text { months. }\end{array}$ & $\leq 0$ & $91 . \wedge \leq$ & $\varepsilon$ & 1.17 & 11 & $9 .$. & $r$ & $1 \cdot \cdot$ & $\because \cdot 7$ \\
\hline rV & $\begin{array}{l}\text { The closure is mandatory, in case of } \\
\text { recidivism and for offences against } \\
\text { copyright and Brand right. }\end{array}$ & $\leqslant 7$ & $9 ז . \wedge 1$ & $r$ & 7.11 & $r$. & $1 \ldots$ & · & $\because \cdots$ & $1 . \mathrm{r} \wedge$ \\
\hline & \multicolumn{10}{|c|}{$\begin{array}{l}\text { * Article (113) of the Egyptian law stipulates that "without prejudice to any heavier penalty in any other law } \\
\text { shall be punished by imprisonment of not less than two months and a fine of not less than five thousand } \\
\text { pounds and does not allow f } 20 \text { pounds or to both": }\end{array}$} \\
\hline rᄉ & $\begin{array}{l}\text { Whoever falsifies registered logo in } \\
\text { accordance with the law or reproduced it } \\
\text { in a way that misleads the public }\end{array}$ & $\leqslant V$ & 90.94 & r & $\varepsilon \cdot \wedge$ & $r$. & $1 \ldots$ & · & $\because \cdots$ & $\cdot \wedge \varepsilon$ \\
\hline rq & $\begin{array}{l}\text { Whoever uses in malice forged or } \\
\text { counterfeit Logos }\end{array}$ & $\leqslant 7$ & $9 r . \wedge \wedge$ & $r$ & 7.14 & $r$. & $1 \ldots$ & . & $\because \cdots$ & $1 . r \Lambda$ \\
\hline$\varepsilon$. & $\begin{array}{l}\text { Whoever puts in malice a Logo owned by } \\
\text { the other on his product. }\end{array}$ & $\leq 9$ & 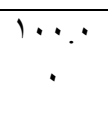 & . & $\because \cdots$ & 11 & $9 .$. & r & $1 \cdot$ & $\begin{array}{l}* 0.0 \\
*\end{array}$ \\
\hline ¿1 & $\begin{array}{l}\text { In the case of reoccurrence, punishment } \\
\text { shall be imprisonment for not less than } \\
\text { two months and a fine of not less than } \\
10,000 \text { pounds and not more than fifty } \\
\text { thousand pounds. }\end{array}$ & $\leqslant V$ & 90.94 & r & $\varepsilon .1$ & $r$. & $1 \ldots$ & · & $\because \cdots$ & $\cdot \wedge \varepsilon$ \\
\hline$\sum r$ & In all cases the Court will judge to & $\leqslant 7$ & $94 . \wedge \wedge$ & $r$ & 7.11 & 17 & $\Lambda \cdot . \cdot$ & $\varepsilon$ & $r \cdot \cdot$ & $*$ r... \\
\hline
\end{tabular}




\begin{tabular}{|c|c|c|c|c|c|c|c|c|c|c|}
\hline & $\begin{array}{l}\text { confiscate the products involved in the } \\
\text { crime, the amounts or whatever was } \\
\text { seized, as well as the tools that were used } \\
\text { in the perpetrators. }\end{array}$ & & & & & & & & $\cdot$ & $*$ \\
\hline$\varepsilon r$ & $\begin{array}{l}\text { Upon conviction, the institution may be } \\
\text { closed for a term not exceeding six } \\
\text { months and closure is mandatory in the } \\
\text { case of reoccurrence }\end{array}$ & $\leqslant \vee$ & 90.94 & r & $\varepsilon . \wedge$ & r. & $1 \cdots$ & · & $\because \cdots$ & $\cdot \wedge \varepsilon$ \\
\hline & \multicolumn{10}{|c|}{$*$ The Criminal Protection of the Famous Logo } \\
\hline$\leqslant \varepsilon$ & $\begin{array}{l}\text { In article } 68 \text { of the Egyptian law "the } \\
\text { owner of the Internationally registered } \\
\text { Famous Logo will have in the Arab } \\
\text { Republic of Egypt the legal protection } \\
\text { even if unregistered in Egypt". }\end{array}$ & $\leqslant V$ & 90.94 & r & $\varepsilon . \wedge$ & r. & $1 \cdots$ & $\cdot$ & $\because \cdots$ & $\cdot \wedge \varepsilon$ \\
\hline$\leq 0$ & $\begin{array}{l}\text { In article } 113 \text { of the Egyptian law "the } \\
\text { criminal protection is organized for the } \\
\text { Logo that fulfill the standard fame } \\
\text { according to Egyptian law. }\end{array}$ & $\leqslant \uparrow$ & $9 \uparrow . \wedge \wedge$ & r & $7.1 \mathrm{~T}$ & r. & $1 \cdots$ & · & $\because \cdots$ & $1 . \mathrm{r} \Lambda$ \\
\hline \multirow[t]{2}{*}{$\leqslant 7$} & $\begin{array}{l}\text { Whoever forges registered logo in } \\
\text { accordance with the law or otherwise } \\
\text { reproduce in such a way as to mislead the } \\
\text { public. }\end{array}$ & $\leqslant \vee$ & 90.94 & r & $\varepsilon . \wedge$ & 17 & $\wedge$. & $\varepsilon$ & r. & $* \varepsilon$ or \\
\hline & \multicolumn{10}{|l|}{ * Crimes committed on Brand } \\
\hline$\leqslant V$ & $\begin{array}{l}\text { Violation of a Brand owned by others and } \\
\text { its placing with the malice by its violator } \\
\text { on his products. }\end{array}$ & $\leqslant \wedge$ & $9 \vee .97$ & 1 & $r . \varepsilon$ & $r$. & $1 \cdots$ & · & $\because \cdots$ & $\because \leqslant 1$ \\
\hline$\leqslant \wedge$ & $\begin{array}{l}\text { Brand forgery of the is the literal and } \\
\text { complete transfer of the registered Logo } \\
\text { so that it looks identical to the original } \\
\text { Brand. }\end{array}$ & $\leqslant \uparrow$ & $9 \uparrow . \wedge \wedge$ & r & $7.1 \mathrm{r}$ & $r \cdot$ & $1 \ldots$ & · & $\because \cdots$ & $1 . \mathrm{r} \wedge$ \\
\hline$\leqslant 9$ & $\begin{array}{l}\text { Reproduction is to take a Brand } \\
\text { resembling as a whole as the original } \\
\text { Brand misleading or deceiving the public } \\
\text { that the Brand is genuine. }\end{array}$ & $\leqslant \vee$ & 90.94 & r & $\varepsilon . \wedge$ & $r \cdot$ & $1 \cdots$ & · & $\because \cdots$ & $\cdot \wedge \varepsilon$ \\
\hline o. & $\begin{array}{l}\text { The resemblance between brands is the } \\
\text { symmetry in bulk of the elements or parts } \\
\text { constituting the Brand. }\end{array}$ & $\leq 7$ & $94 . \wedge \Lambda$ & r & $7.1 \mathrm{r}$ & 17 &.$\wedge$ & $\varepsilon$ & $r \cdot \cdot$ & $\begin{array}{c}* r . . \\
*\end{array}$ \\
\hline
\end{tabular}

\section{The value of " $n$ " at the function level $(0.01)=2.617$ and at $(0.05)=2$}

Table (6) showed $\mathrm{t}$ values of $\mathrm{Ka}^{2}$ are greater than the index value the level of index (0.05) in the phrases. It can also be seen that the approving percentage of the axes phrases were high in values ranging from $(71.0 \%$ to $100.0 \%)$ for the senior management sample and from (70.0\% to 100.0$)$ for the investors sample, with a "yes" approval on the phrases. The search sample consented on phrases (from 26 to 29). Article (61) of the TRIPS agreement stipulates the commitment of Member States to apply at least the procedures and the criminal penalties in cases of the registered deliberate reproduction of the Brands or copyright theft on a commercial scale. As stipulated in article (61) of the TRIPS agreement, imposed sanctions could include "imprisonment or fines" enough to provide sanctions commensurate with the level of the penalties applied for crimes of comparable gravity and in appropriate cases. Imposed sanctions may include also sequestration of infringed goods and any equipment mainly used in 
the offence to be confiscated and destroyed. Countries member in TRIPS agreement may impose the procedures and the criminal penalties in other cases of infringement of intellectual property rights, especially where it is deliberately modified and on a commercial scale.

Al-Azhari (1988) mentioned that the brand has protection goals, it protects the product from the potential manipulation of some distributors and of their difficult attempt to succeed to convert the demand of a product of an institution to another product of another institution or likely to the falsification or to the reproduction of other organizations.

Keller (1998) mentioned that the strength of the legal protection of the various elements of the Brand is a radical prerequisite for its strength. The legal protection means that any Brand that is protected should not be used to distinguished by any other product, reproduced, falsified, or that the brand be exposed for sale or for exchange.

Results of Wala'aEldin (2006) covered the Brand's legal protection where she refers to the inability to reproduce the mark of various organizations as they invent names, logos, colors and music particular to the brand by the Organization and therefore are protected by it.

The researchers assured that for the criteria for selecting the Brand that it must have a unique style and be distinguished from other Brands. On the other hand it should not have been previously employed or used, be fairly new, can be used in all methods that it used for, easy to design, has a simple form, could be remembered easily by any individual, and also can be registered as a Brand, and does not look similar to any other brands or any other institution name and does not contain any opposition against the public order, the State logos, the media or symbols.

As for the criminal protection of the brand mentioned in phrases $(30,31,32,33,34,35,36$, 37 ) the research sample agreed on the content of the articles under the Egyptian law No. (82) of 2002 on the protection of intellectual property rights: warmed about offences against patents, designs undisclosed information, crimes on Brands, trading data, geographical indicators, and industrial designs and industrial models, offences crimes against copyrights and neighboring rights and offences against property rights in plant varieties, offences crimes against copyrights and neighboring rights and offences against property rights in plant varieties. Article (61) of the TRIPS agreement stipulated on certain penalties ranging from imprisonment and a fine or both, the Egyptian legislature allowed when convicted the judgment may require the closure of the institution that the sentenced exploited for committing the crime for a term not exceeding six months, the closure is mandatory, in case of recidivism and for offences against copyright and Brand right.

According to the recommendations of Abdeen (2011), there is a need to follow legal procedures in registering the Brands and the intellectual property rights for sports institutions. To adopt legal law regulating the relationship between the Brand owner, the franchisee and the authority responsible for the registration, documentation of these Brands (licensing awarding authority). To establish a justice specialized in the sport domain to ensure the prompt disposition of intellectual Property disputes in sports domain To ensure the issue of legislation guaranteeing the rights of the organizers of tournaments (federations - clubs sponsors radio and television-Internet) for nonoverlapping issues between them, finally the sports institutions register their Brands and their property rights, and renew the registration of their Brands in accordance with the local Brands rules.

El-khedr (2005), confirmed that the brand awareness is an important element in the process of building a strong brand. Awadallah (2008), study's results also recommending that the strength of the sport institution's Brand derives its strength from the awareness of the recipient and to their loyalty to the Brand. He indicated that the results of all sports institutions have the right to protect their brands by all means enabled them by law while underlining that the sports institutions have to register and promote their Brands.

The criminal protection of the famous logo the crimes that are committed against it, the research sample views agreed by consent ranging from 93 to $97 \%$ for the phrases $(44,45$, $46,47,48,49$ and 50) and the stipulation of 
article (68) of the Egyptian law covering the Criminal Protection of the Famous Logo "the owner of the Internationally registered Famous Logo will have in the Arab Republic of Egypt the legal protection even if unregistered in Egypt". Also article 113 of the Egyptian law "the criminal protection is organized for the Logo that fulfill the standard fame according to Egyptian law. Whoever forges registered logo in accordance with the law or otherwise reproduce in such a way as to mislead the public. In addition to the crimes committed on Brand Violation of a Brand owned by others and its placing with the malice by its violator on his products. Counterfeiting of the Brand is the literal and complete transfer of the registered Logo so that it looks identical to the original Brand. Reproduction is to take a Brand resembling as a whole as the original Brand misleading or deceiving the public that the Brand is genuine. The resemblance between brands is the symmetry in bulk of the elements or parts constituting the Brand.

According to the Paris Agreement, the established protection accorded to the Famous Logo does not arise from its registration or its use, and it arises from simply being famous the State where it needs to be protected even if it is unregistered. This means that it is sufficient to consider that the Famous Logo is widely known through publicity campaigns and advertisement without requiring that the products bear the Logo have been marketed in that State. The Egyptian court of Cassation decided in appeal No. 543 of 37 may 1967 that the example is in similarities but not in the degree of difference between the Logos, but the extent of similarity in appearance which will lead to the confusion of the common man.

Zain El-din (2000) confirmed that the brand serves as a guarantee for the protection of recipients, as well as a mean to advertise products and therefore warn against the using of the Brand owned by any institution without a license so as not to create any confusion or in distinctness to the recipients.

El-Shafei (2009) mentioned that the license contract is that the owner of the absolute rights of the Brand grants another party his permission or his approval to carry out work that would have been considered in violation of the rights conferred by the Brand owner if unauthorized.

As stated by Wala'aEldin (2006) and according with the European Court of Justice (2002) the Brand owner has the right to prevent any third parties from using his Brand. Also the court endorsed the commitment of the States Members to grant the legal protection for the use of non-owners of any identical or similar Brand to a registered Famous Logo, even if the Brand is not identical or not reproduced it is not necessary that there is a possibility to risk indistinctness or confusion between the Brand and the Famous Logo to be a violation of the Famous Logo.

Al-Saghir (2003), confirmed that the legal protection of the Brand does not arise from its registration or its use but arises from been fame in the state where it needs to be protected, and this means it is sufficient to establish a Famous Logo is to be known widely through publicity campaigns and advertisement without requiring that the product which bears the brand was marketed in the State.

According to article (6 II) of the Paris Agreement, the members of the Agreement are committed to provide the legal protection of Famous Logo through the competent administrative authorities by taking the following actions: the rejection of the registration of any similar or comparable Brand of the Famous Logo in case that application is made by someone other than the Brand owner. Deregistration of the similar or comparable Brand to the famous mark, El-Shafie (2006).

The researchers revealed that the selection of the Brand is one of the most important processes at all stages and should be given a great deal of attention. Since, any mistake committed by the institution at the beginning of the selection of the Brand may encounter consequences that may be difficult to remedy, and may entail the need for efforts and expenditures that could have been provided to another more important activity. Therefore, we consider when selecting a Brand to consult specialists in criminal and civil laws so as to assist the institution in achieving the desired goal of Brand and to refer to laws which stipulate Civil and criminal protection. 
Also the researchers perceived the important need to follow all procedures and legal aspects in the registration of the Brand, the intellectual property rights of the sports institutions. There is also a need that the sports organizations register their own Brands and the intellectual property rights. In accordance with the Egyptian law, Sports institution and Sports organizations will renew the registration of Brand registration. Also there is a need to develop legislation and regulations and sports courts specialized in sport domain to ensure the expeditious adjudication of disputes and issues concerning the rights of the intellectual property rights in sport domain on how to use sports institutions Brands in commerce such as : the tools, the sportswear and non-sportswear, the sports events and festivals. In addition, work must be done on issuing legislation that will govern the rights of both the persons in charge and the organizers of tournaments in every sports domain such as the sports federations, the clubs, the official sponsors, the television so non-overlapping issues can stand between them. There is also a need for legal legislation regulating the relationship between the brand sports institution, the franchisee and the agency that register and record these Brands.

\section{Conclusions}

Based on the above discussion of the study results and comparison with the other related previous studies, the researchers concluded that Brands of famous sports institutions are usually subjected to thievery operations either by theft or by reproduction. Some may not realize that such operations have an important economic and commercial dimension. These Brands are exploited by sports institutions to draw financial resources to support budget and overheads in their various activities through allowing the business investment institutions in various fields to place these Brands on a wide variety of miscellaneous products.

The methodology of this study indicated the most useful approach: the trade mark clearance search will identify whether the same or a similar brand has already been registered, whilst the internet searches may identify unregistered trademarks which are being used by other companies.
The strongest form of protection for a sport brand is a registered trade mark. Basically, sport trademarks identify the products or services of traders, to enable consumers to distinguish between the sport products and services of different traders. If a trade mark is registered, special rules apply which simplify the way in which it can be protected. Unregistered trademarks can also be protected; however, it is much cheaper and easier for the sport business to enforce its rights in a registered trade mark than in an unregistered trade mark. For this reason, sport businesses should consider obtaining registered trademarks to protect their brands. Most countries have their own systems for trade mark protection and registration. There are also European and international systems of protection.

Discussion of the results derived from the method used in this study lead to the following interpretation of the two main axis titles. According to Axis I entitled the civil protection of the Brand in sports institutions,

- The banning of any acts whose nature may create any means of confusion with other competitors, their products or their various activities.

- The use of any Brand owned by third parties or other sporting institution, or otherwise reproduced is considered as acts that create indistinctness and confusion between the products or services.

- The civil protection of the Brand name in accordance with the public law in England on the base of the illegal competition. and

- On the basis that the trade practitioner using fraudulent methods to attract more users to the product, service or activity which harms the institution or just likelihood.

- Under the act, the law authorized the victim of unfair competition to lawsuit against the aggressor requesting prevention of violation and asks for compensation for damage, in addition to that, the potential publication of the judgment in a daily newspaper at the expense of the convicted offender.

- The Famous Logo is the logo known over time and coexisting with the generations such as Al-ahly, $\mathrm{Al}$ Zamalek, $\mathrm{Al}$ Itihad $\mathrm{Al}$ Sakandary, Al Ismaily and other prestigious sporting institutions. 
According to Axis II, entitled criminal Protection of the Brand in Sports institutions, most of the sample views agreed on the following:

- The law No. (82) of year 2002 on the protection of intellectual property rights warmed about the offences against patents, designs and the undisclosed information. While, Article (61) of the TRIPS agreement stipulated on certain penalties ranging from imprisonment or a fine or both penalties.

- The Egyptian legislature allowed when convicted the judgment may require the closure of the institution that the sentenced exploited for committing the crime for a term not exceeding six months.

- The closure is mandatory, in case of recidivism and for offences against copyright and Brand right.

- Whoever falsifies registered logo in accordance with the law or reproduced it in a way that misleads the public. Whoever uses in malice forged or counterfeit Logos, in article 68 of the Egyptian law "the owner of an International registered Famous Logo will have in the Arab Republic of Egypt the legal protection even if unregistered in Egypt".

- The crimes committed on the Brand, forgery and reproduction. Brand Forgery means the literal and complete transfer of the registered Logo so that it looks identical to the original Brand.

- Imitation is to take a Brand resembling as a whole as the original Brand misleading or deceiving the public that the Brand is genuine.

\section{Recommendations}

The importance of this study and the results extracted lead the authors to suggest, some recommendations for applied in the near future and to be as lesson learned for the beneficiaries of such these studies. These recommendations are:

- Following the legal procedures in the registration of a trademark and intellectual property rights to sports and institutions that likewise came as Egyptian law No. 202 (individual property rights to be informed of Commerce)

- Developing agreements Arab property rights for the brand.

- Need for a legislative and legal formulas to ensure the legitimacy of the owners of sports projects that contain the trademarks and the establishment of a mechanism by the beneficiaries as a regulatory action on any violation of trademarks for sports organizations.

- The need for adopting of legislation governing the legal relationship between the brand owner, the owner of the right of exploitation and the granting authority issued the license of the brand.

- The need for a provision in the law field sports specialist to ensure prompt settlement of disputes concerning the domain sports.

- The need to issue legislation and laws on sports bodies to how the commercial use of slogans such as tools, clothing, sporting events.

- Elaborating of an Arab Agreement on the rights to the brand.

- The establishment of specialized courts for intellectual property disputes.

- The use of all kinds of compensation as a deterrent.

- Consumer awareness as per the importance of Brand products and services in the Arab and Egyptian market.

- The need to apply all administrative and legal procedures when registering sports institutions Brands for sports events and consider the renewal of the Brand registration according to the rules in force.

- Emphasizing of regulatory action against Brands violators of sports organizations.

\section{References}

Awadallah A. K. Mahmoud, 2008. "A Proposed Plan for the Protection, Marketing and Investment Brands in Sports System", unpublished MPhil, Faculty of physical education for boys, the pyramid, Helwan University.

Mehran A. F. A. A., 2001. Administration of names and logos and their impact on the marketing strategies of Egyptian companies, 
unpublished Phd, Faculty of Commerce, Cairo University.

Al-Saghir H. E., 2003. Modern Trends in the Protection of Brands, WIPO National seminar on Brands, the World Intellectual Property Organization (WIPO), Syria.

El-Shafei H. A., 2006. Investment and Investment in Physical Education and Sports, I 1, Dar El Wafa'a, Printing and Publishing House.

El-Shafei H. A., 2009. TRIPS - WIPO Franchise in physical education and sport, I 1 Dar El Wafa'a Printing and Publishing House.

El-Shafei H. A., 2006. Financing and Lease Financing in Sports, Dar El Wafa'a Printing house, Alexandria.

Al-Bishtawi D. T., 2008. Franchise contract and its impacts, unpublished MPhil, High Studies Faculty, Al-Najah National University, Nablus, Palestine.

Abdin D. M., 2011. Investing Brands in sports marketing, unpublished $\mathrm{PhD}$, Faculty of physical education for girls, Alexandria University.

El-Sadik S. A., 2003. Mates logos and Arabian Calligraphy, published paper, Journal of marketing and advertising the fifth year, $\mathrm{N}^{\mathrm{o}}$. XVII.

Zainuddin S., 2000. Industrial and Trade Property, Cultural Publishing House Library and Distribution, Oman, Jordan.

Almekdadi A. A. (without). Brands Legal Protection in the Jordanian Law. Electronic Arabian Law Guide www.arabawinfo.com

AlKeswany A., 1998. Brands" Blessing or Curse, Journal of intellectual property protection, N. (56), Oman, Jordan.

AbuNab'a A.M., 2002. Principal of Modern Marketing between Theory and Application, I 3, Zaitouna University, JordanDemresh A., 1998. The International protection of industrial property and its legal applications, Faculty of Law, Casablanca
Ibrahim A. A. D., 2006. Brand enrollment methods in designing advertising campaigns in Egypt, unpublished Mphil, Polytechnic, advertising section, Helwan University.

El-Khatib F. S., Awad M. S., 2000. Principles of Marketing (basic concepts) first edition, Oman, Dar El Fikr Publishing and Distribution House

EL-karim F. A., 2007. Investment Departments an important requisite in sports clubs. Al Riyadh Daily, N $^{\mathrm{o}} 14167$, KSA

Law on the Protection of Intellectual Property Rights: No. 82 of 2002, entitled "Brands and Trade Data and GI article 63.

Brands Owner Magazine, 2002. Ministry of Economy, Abu Dhabi, United Arab Emirates

WIPO Magazine, 2002. www.wipo_magazine

Al-Khedr M. S. 2005. An analytical study of the factors affecting University students loyalty to brands of non-durable goods marketing, unpublished MPhil, Faculty of Commerce, Department of Business Administration, Ain Shams University.

Mahboubi M., 1999. Brands Registration, Law University, Casablanca

Abdel Hamid M. A., 2006. Brand and methods of protection in accordance with the laws in force in Palestine, unpublished MPhil, Hidh Studies Facukty, an-Najah National University, Nablus, Palestine.

Al-Azhari M. A., 1988. Marketing Activity Department, Strategic Portal, Dar El Fikr Al Arabi, Cairo.

Wala'aElDin M. A., 2006. Legal protection of the Brand in Private International Law, unpublished $\mathrm{PhD}$, Faculty of Ain Shams University.

Keller, K. L., 1998. Franchise Relocation \&Introduction : A Sports Marketing Case Study Hurricans, Journal of Services Marketing, MCB University Press.

Lin C., W. \& Wang Z., 2000. Strategic Brand Management, (New Jersey :Prentice - H 
